Article

\title{
The Unmade City: Subjectivity, Buffalo and the Sad Fate of Studio Arena Theatre
}

\author{
Julian Meyrick
}

School of Humanities and the Creative Arts, Flinders University, GPO Box 2100, Adelaide, SA 5001, Australia; julian.meyrick@flinders.edu.au; Tel.: +61-882-012-595

Academic Editor: Peta Tait

Received: 19 May 2016; Accepted: 24 August 2016; Published: 1 September 2016

\begin{abstract}
This article is a reflection on the disjointed and submerged cultural consciousness of the city of Buffalo, New York. It outlines the concept of subjectivity as put forward by the philosopher Alain Badiou, and maps it onto the history of Studio Arena, Buffalo's main theatre company. Studio Arena Theatre (1927-2008) was one of the oldest and best known regional theatres in the USA. Its closure is a story fraught with conflict, misunderstanding and loss. That there has been no replacement theatre of comparable size and mandate says something about Buffalo's diminished civic imaginary. While the link between the Theatre and the City is hard to formularise, it is a historically important relationship, going back to the time of Aristotle when theatre functioned as an informing resource for the lives of citizens. Those interested in urban renewal in Buffalo and other rust-belt US cities can profit not only from an understanding of Studio Arena Theatre's history, but from a consideration of the kind of emotional engagement that this regional theatre represented.
\end{abstract}

Keywords: theatre; city; Badiou; regional theatre; Studio Arena

Yet once more I dream. Once more a voice says:

Build a house for the sun, with a winding stair

for the wandering light to go up and rest

before labour.

Cold, cold are the winds from the unmade world.

“Port Sunlight” by Allen Grossman [1].

Theatre spaces are unique because they are intended for unique forms of human interaction. When they are abandoned, they are stripped in a way that factories and offices are not. Theatrical performances are ephemeral. But theatre spaces are built with permanence in mind. They wear their past on their sleeve. What was is almost more apparent than what is.

Timothy Neesam, photographer [2]. 


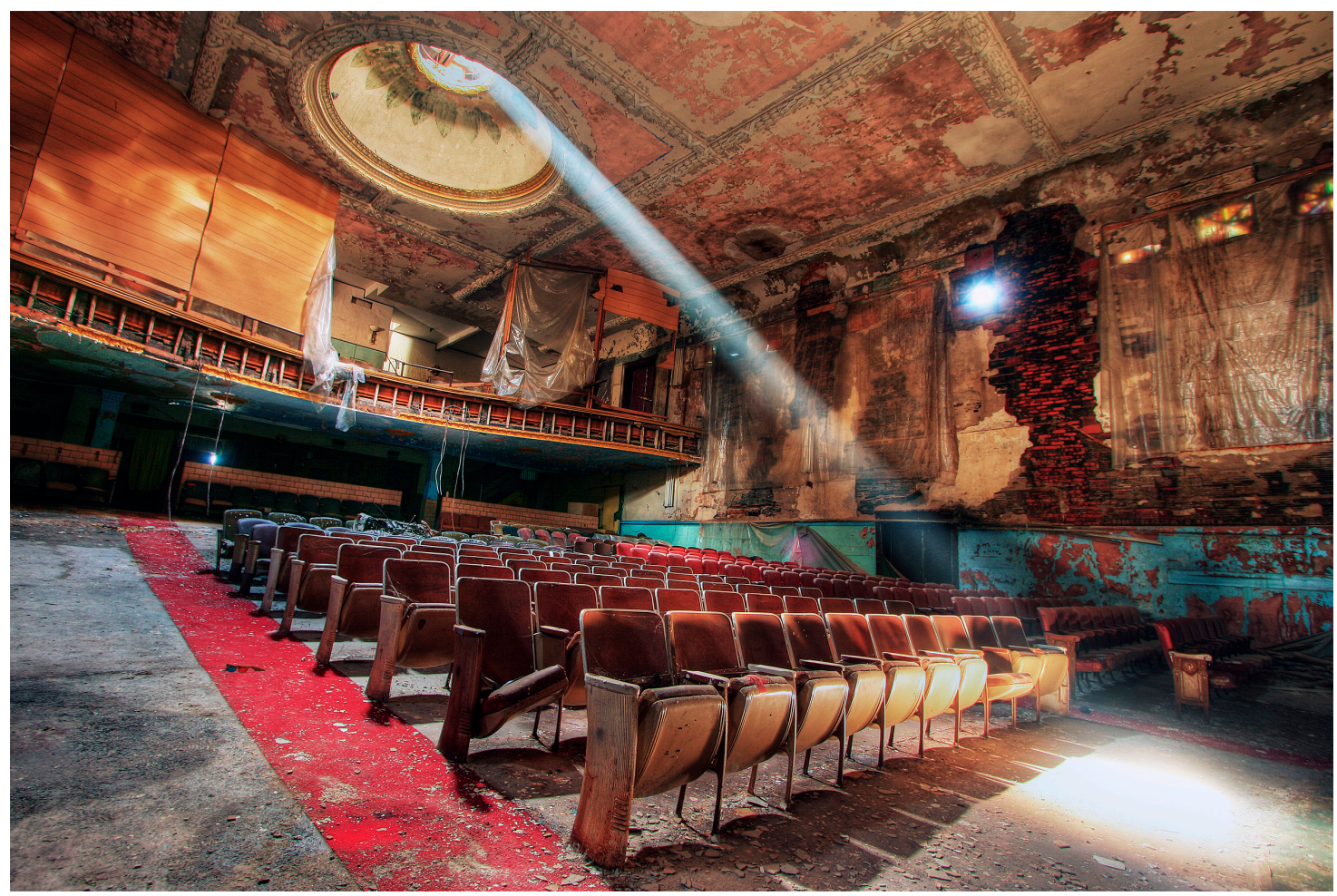

Figure 1. "Broadway" by Timothy Neesam.

\section{Introduction}

There are three main ways to think the link between "the city" and "the theatre". The first is to elaborate a history of their co-signification, as Marvin Carlson does in his classic study Places of Performance (1989) [3]. Urban planning, theatre architecture, and political analysis come together to render a lapidary, spatialised semiotics. The second is to eschew history for social description, like Howard Becker in Art Worlds (1982) [4], and treat it as a subsystem of a broader cultural ecology. For Chicago School sociology, theatre is a "case" whose interactions mirror the frictions of the wider world around it. Both approaches furnish an intellectual vista that stretches in two directions: the theatre is "read" into the city, even as the city is "read" into the theatre. This generates an infinite number of interpretations. There is no end to what can be said about the city-theatre dyad, and no sense that anything said might found the relation beyond what can be directly observed or plausibly inferred. How different from the third approach which conceives the dyad not as a category of object but as a site for agency, emotion and will. Here, semiotics gives way to phenomenology, sociology to social activism. But what system of thought can articulate this different orientation, yet demonstrate a grasp of historical and ethnographic detail? What analysis can supply a theory of the subject adequate to the complex reality of the empirical world?

This article is written in the subjunctive mood. It is not an account of the relationship between the city of Buffalo, New York, and Studio Arena Theatre-a complicated and conflicted story exceedingly hard to summarise. It is only an outline of what such an account could involve if the task were taken up in earnest: a sketch of potential areas of investigation, of the events that shaped the company's trajectory, and of its mandate-or ruling idea-determining who did what at key moments in its 81-year life. Studio Arena was a so-called regional theatre, one of the oldest in the USA, and a major Buffalo cultural institution. However, the term "regional theatre" does not explain, much less exhaust, the emotional meaning of the company-a meaning that was fought over and fought out 50 years before that phrase was even coined. 
The theatrical past is a tapestry of movements, waves and synchronised institutional elaborations. It is this cohesion that gives theatre companies their metonymic link to the cities providing their context and support. We take the link for granted even as its changing valency commands our attention. Theatres are things that cities are presumed to have as a matter of course, their values and operation a means by which a larger civic identity is projected. How do such relations begin? More pertinently here, why do they end? What do these foundational and terminal moments mean to those involved in them, as acts rather than facts? When Studio Arena started, at the turn of the twentieth century, Buffalo was the third wealthiest city in the USA. In 2009, the year the company closed, it was the third poorest. Between these two chronological markers lies a cascade of disasters of different but related kinds. Was the company's demise a result of Buffalo's deterioration, or a trigger for it? What is declared when a city like Buffalo is no longer capable of supporting an organisation that has been part of its collective life for nearly one hundred years? The politics of decline are accompanied by an aesthetics of decay that bear haunting witness to its human cost. But the sense of ruin is never total, never complete. Photographs hint at the powerful atmosphere exuded by abandoned theatre buildings (Figure 1). We feel a living spirit moving through these devastated places still. Why? How? We are back to the need for a theory of the subject. For what persists through time, as opposed to what just occurs in it, requires deeper construal than historical or sociological description can provide. Hope lives in thought even when everything in brick and stone crumbles around it. One might say that there are emotional fundamentals in the theatre-city dyad that transcend the material conditions whereby they are expressed, even though they have no concrete expression outside those conditions.

It is at this juncture that we can turn to Alain Badiou-mathematician, Marxist and neo-Platonic philosopher-whose recent writings have done much to bring together analytical, Continental and post-structuralist strains in contemporary Western philosophy [5,6]. Badiou's major works L'Être et l'événement (1988) [7] and Logiques des mondes (2006) [8] resuscitate ontology as a critical line of inquiry and equate it with mathematics (his precise formulation is: "ontology is mathematics"). It is hard to summarise Badiou's complex theories, or their chief feature, the use of Cantorian set theory. But one notion can be explored relating to what is of interest here: the problem of the subject and the appearance of truth. For Badiou, the world is one of subjects, or rather, of people seeking subjectivity. A truth presents in the form of an event, an eruption in established knowledge that forces into existence a new configuration of thought: a new "idea". Until its appearance, this truth is indiscernible, unnameable, undecidable. Afterwards, it has the power of a binding insight. It is the need to be faithful to the consequences of an event that creates the subject. Arising from nothing, it commands an absolute fidelity. Peter Hallward explains:

Truth is...a matter of conviction first and foremost, and every subject demonstrates "what a conviction is capable of, here, now, and forever". The word truth (vérité), as Badiou uses it, connotes something close to the English expressions "to be true to something" or "to be faithful to something". What Badiou calls subjectivization essentially describes the experience of identification with a cause, or better, the active experience of conversion or commitment to a cause-a cause with which one can identify oneself without reserve. "Either you participate, declare the founding event, and draw the consequences, or you remain outside it," he writes. "This distinction without intermediary or mediation is entirely subjective". The identity of the subject rests entirely, unconditionally, on this commitment...It is only in such rare moments of pure engagement, Badiou suggests, that we become all that we can be, that is, that we are carried beyond our normal limits, beyond the range of predictable response...Truth, subject, and event are all aspects of a single process: a truth comes into being through the subjects who proclaim it and, in doing so, constitute themselves as subjects in their fidelity to the event ([5], p. xxvi).

Badiou's approach is a sharp break with those theories of the object that have dominated humanities discourse in recent years, and it returns certain ideas back to intellectual legibility: the role of the event; the inevitability of risk; the reality of choice; the possibility of agency; the revolutionary 
impact of truth [9]. All these shape the subject, positing subjectivity as something emotionally achieved. Something happens, and a changed situation presents itself. The event is seized upon as providing a new understanding, which provides paths for its verification for those who would be faithful to its consequences.

To participate in the affirmation of a truth involves, in any given world, active incorporation into the subject body or corps of that affirmation. Such incorporation provides Badiou with his definitions of a true worldly life..."To live is to participate, point by point, in the organisation of a new body in line with what is required by a faithful subjective formalism" ([10], p. 108).

A final observation about this notion of the subject: the basis for subjectivity is division, or as Badiou puts it more suggestively in St Paul: The Foundation of Universalism, "the constituting weave through which [someone] is related to [a] situation as it is and to the effects of [an] event as they have to become" ([11], p. 63). This is a crucial point. It freights the whole notion of the subject in Badiou's onto-historical transcendent materialism. The eruption of an event creates a scission within the subject-the residue of the person they were ante the event, the emergence of the person they are post. Subjectivity is created by subjects accounting for an event. Crucial to this "truth procedure" is the concrete relation between the effects of a truth, which are dispersed and universal, and its geographical and historical coordinates, which are localised and specific. St Paul is a book about just this: the relationship of a truth to its evental site. Cities are important centres in St Paul's post-evental proselytising (Jerusalem, Antioch, Athens, Rome), even though the truth he proclaims is universal (Jesus is Resurrected). Badiou is a third-generation atheist and is not concerned with the theology of all this. As he says, "I have never really connected Paul with religion" ([11], p. 1). His focus is the intersection between truth and site that allows Thought to manifest as radical declaration. With this manifestation comes, in its wake, the subject, facing down the contingencies of historical existence even as he or she tries to be faithful to what Badiou oxymoronically calls a "universal singularity".

\section{Buffalo and Studio Arena Theatre Narrative}

How to apply Badiou's writings, so uninterested in the mundane tasks of historical and social description, to the sad fate of Studio Arena Theatre? A starting point might be to compare its history with Buffalo's and to tease out the parallels, especially the economic nose-dive that affected them both (more detail is provided in Appendix A). In 1920, Buffalo had a population of 506,775 and was the 11th ranked city in the USA. By 1970, it had fallen to 462,768 and the city was the 28th ranked. By 2000, the population had dropped again, to 292,480 and Buffalo was the 57th ranked. The story behind these chilling statistics is by no means unique in North America's industrial heartland.

The Studio Club was formed in 1901-the same year Buffalo hosted the Pan-American Exposition-as an "informal organisation [that] came together [to] spend evening[s] reading poetry, setting it to music, [and] doing play[s]" [12]. The city's economy was flourishing in a variety of industries and sectors: iron and steel, chemicals and manufactures, agriculture and shipping. The population was ethnically divided, with a white, Anglo-Saxon Protestant (WASP) elite presiding over Irish, Polish, German and Italian neighbourhoods. In the 1920s, the Studio Club morphed into the short-lived Buffalo Players, while the city became more of a branch town, controlled by interests whose interests no longer lay in Buffalo. Wealth and influence exited to Chicago, Cleveland and New York City. In the 1930s the Depression hit. The company, now called Studio Theatre, won a prestigious play competition, the Belasco Cup Series, and secured a Rockefeller grant to refurbish an abandoned church on the corner of Lafayette and Hoyts Streets. It remained their home for the next 30 years. Buffalo, sporting 13 trunk line railroads and an active port, also showed resilience retaining an array of top-flight companies: Westinghouse, Remington, Bethlehem Steel, Dupont, Union Carbide, Hooker Chemical. In the 1940s, 1950s and 1960s, riding on the back of successive war booms, Buffalo regained industrial strength. 
In 1965, the company made a last name change, to Studio Arena Theatre, and turned professional, becoming a key player in the regional theatre movement. A zenith was reached in 1968 when it premiered Edward Albee's Box Mao Box-Albee's reputation then in the ascendant after the success of Who's Afraid of Virginia Woolf. "For one night, Buffalo was the centre of the entire theatre world. By coaxing the nation's press to Buffalo's door, [the company] proved the goals of the regional theatre movement were not illusory", says Anthony Chase [13]. For the city, things were also good, but underlying problems had started to surface. In 1959, with the opening of the St Lawrence Seaway, Buffalo lost its role as a major inland port and the wheat trade with it. The 1960s saw the beginnings of a population relocation to the outer suburbs ("white flight"), while political power was awkwardly divided between City Hall, run by the Democratic Party machine, and the WASP professional elite, increasingly composed of out-of-towners. Successive inner-city regeneration plans all ended disastrously: the (mis)location of a new university campus; the building of a (too-limited) rapid transit system; the (misjudged) site of a new football stadium; the contracting of a (failed) downtown conference centre. Splits, infighting and dissention increasingly marked Buffalo's leadership and, in 1977, after the Organization of Petroleum Exporting Countries (OPEC) oil crisis and a decade of union-management strife, the Chairman of Bethlehem Steel warned that the city was "heading towards the ashcan of history" ([14], quoted on p. 113).

In 1980, Studio Arena fired its then Artistic Director, Neal Du Brock, the architect of its previous success, and settled into drawn-out decline. There were rallies: an interesting series of "Buffalo plays" in the 1990s, for example, that included Tom Dudzick's local hit, Over the Tavern, and an A. R. Gurney's commission, The Snow Ball. But after 2000, matters rapidly fell apart. In 2005, following losses on a Broadway misfire, the company announced a deficit of $\$ 1.4$ million. In 2007, it laid off staff and scaled back to six shows a year. In 2008, it filed for what is termed "Chapter 11 bankruptcy" in the USA. Finally, in 2009, with debts of over \$3 million—-the majority owed to its own endowment-it filed for "Chapter 7 bankruptcy" and effectively ceased to exist.

During the same period, Buffalo lost most of the rest of its manufacturing base. Low-paid employment swelled as state and federal money was injected to save the city's economy, like blood into a dying man's veins. Public funding ballooned to 50 per cent of annual revenue. In 2008, the Global Financial Crisis (GFC) hit the USA and Buffalo's story became at once unremarkable and overlooked. By 2011, its population had fallen to 261,310, and the city to the 70th wealthiest in the USA. While the corporate bodies presiding over its fate bickered among themselves, the one thing Buffalo really needed to break a drop into poverty and despair seemed to disappear: an effective civic will. From a reading of Mark Goldman's City on the Edge [15] ${ }^{1}$ and Diana Dillaway's Power Failure [14],2 Buffalo's situation comes across as one not only of diminishing resources but of emotional confusion, hastened by the antagonistic behaviour of political, business and community leaders, and by a federal indifference that wrote the city off as not worth rescuing. Poor leadership in its last years was Studio Arena's story, too. This is hardly surprising. The boards of Buffalo's arts organisations reflected the elite domination of other areas of its metropolitan life. The same names and families crop up again and again in the narrative of this "big small town" ([14], p. 161). History must judge them harshly, given the results. It is in this sense that I put forward the idea that Buffalo was "unmade" - the word meaning "to reverse", "to deprive of rank", "to destroy", "to bring to nothing" (Oxford English Dictionary, un'make, verb). My intention is to name the effect of an extended catalogue of civic defeats: the devastation of Buffalo's identity, the ruin of the city as a site for evental truths, and thus for emotional subjectivities.

Buffalo's history has been covered by a number of authors [14-17]. Studio Arena's chronology is less well known, so any account of the city-company dyad needs to supply the details. Though

See especially ([10], Chapter 9, "Lightning Strikes: Art and Life during the 1960s", pp. 221-54).

Dillaway has been criticised for not naming the sources of her information about the behind-the-scenes manoeuvring in Buffalo during this period. Despite this, and a compressed and acronym-thick narrative, her study lays out the saga of the city's post-war decline with accessibility and force. 
it changed name, structure and venue a number of times, it remained basically the same company. The archives reveal three personalities who stand out. ${ }^{3}$ First, Marion deForest, President of the Buffalo Players 1922-1927. She was the drama critic for the Buffalo Express, adapted Little Women for the commercial stage, and was also instrumental in founding the Buffalo Philharmonic Orchestra. Next, Jane Keeler, Director of Studio Theatre 1927-1958. She was head of Speech and Drama at Buffalo State College, founded the Studio school when the Players wound up after 27 shows, and raised \$30,000 in the middle of the Depression to outfit a deserted church as a theatre. And finally Neal Du Brock, Studio Arena's most successful Artistic and Managing Director-he wore both hats-from 1965 until his unceremonious sacking in 1980. This charismatic and talented man took the company from "a group of amateurs who happen to think theatre is a very exciting hobby" [18] to a major regional organisation in a few short years, relocating it to a 600-seat venue downtown in what is now the Theatre District, and securing it a reputation which, if not as grand as later claimed, nevertheless put Buffalo on the national theatre map. Both Studio Theatre and Studio Arena Theatre kept up the Buffalo Players' pattern of producing between seven and 10 shows annually. Thus Keeler directed or oversaw the production of some 220 plays, Du Brock just under 140. ${ }^{4}$ After Du Brock left, the theatre was run by successive English directors: David Frank (1980-1991), then Gavin Cameron-Webb (1991-2005). This period was one of effective collapse, though the blame was given to the company's last, ill-fated CEO, Kathleen Gaffney, who fielded just one season of her own, and that cut short after two shows. Du Brock's firing is generally attributed to his reckless lifestyle and even more reckless spending-a failure to control costs at a time when the National Endowment for the Arts was cutting back support for theatre across the country. Thereafter, a number of Managing Directors were installed by Studio Arena's board to ensure better financial planning. But they turned out to be as unsuccessful as their Artistic Directors were uninspired-"a bumbling crew of regional hacks all" as Chase later described them [19].

Thus from a panoptic view, the trajectory of the company and of Buffalo have compelling similarities. Both start with confidence and a great deal of social capital. The 1920s are years of expansion, when they take on, perhaps, more than they can chew. They survive the Depression, to enjoy, during the 1940s and 1950s, steady growth. In the 1960s comes a sense of a "new Buffalo" and a new theatre for it. But the 1980s brings creeping malaise and it is hard to tell whether internal or external factors are to blame. Does the company fail the city or the city the company? From 2005 onwards, it is a moot question; too many things are going wrong. Studio Arena is a company out of luck, money, time and ideas. When the County's Cultural Resources Advisory Board announce that they are considering withdrawing their support, they argue, "What we saw [in Buffalo] was 16 other theatres [providing] plenty of opportunity to view quality theatre...Studio Arena offered no great alternative for funding over the others. Each theatre has its distinguishing character...Studio Arena isn't unique" [21]. Thus the company was, in a media phrase that says it all, "zeroed out" from the cultural equation, its final disappearance coinciding with a nation-wide downturn where whatever plans Buffalo had for its future were also void.

A history of Studio Arena and Buffalo city would need to scrutinise all these aspects of their shared life: the type and number of plays that were staged; the successive artistic and management regimes; the wider policy environment. Since theatres are capitalised enterprises, financial and audience analysis would need to accompany artistic critique and biography. To some extent, the story of the company is the story of its buildings. The Buffalo Players took on the Allendale Movie Theatre in Allentown, which proved too large. Under Keeler, the Studio school moved to a hall in Elmwood, then to the second floor of the now-demolished Teck Theatre, then to a Universalist Church-all of which proved too small. Du Brock moved the company back into bigger spaces, remodelling first the Town Casino, then, in 1978, the Palace Burlesque Theatre. Audiences went up and down, not

3 For biographies of these and other key company personalities, see [20].

4 I am grateful to Anthony Chase for providing me with a complete list of Studio Arena Theatre's productions. For a list of productions by the Buffalo Players and Studio Theatre, see [20]. 
always in synchronisation with what the company was trying to accomplish. The Buffalo Players had 3000 members. After it became Studio Theatre, it lost all but 600. When Du Brock joined, membership was back to 2000. He increased it to 13,500. Thereafter, it reduced again. By 2002, it had fallen to 8000; by 2008 , to 5000 .

Do we stop here? When we have described all the material features of a theatre, have we adequately explained its meaning and value? When we have observed the parallels between company and city, do we draw whatever cautionary tale this is supposed to furnish and move on? Following Badiou, I propose that Studio Arena presents not only the detritus of organisational demise-so many play programs, board minutes, old scripts, empty buildings etc.- - but a train of ongoing thought. This thought should not be exclusively identified with its institutional existence, though it was intrinsic to it. This is a delicate point. The company was an historical entity. It appeared at a certain moment in time, in a certain place. But its spirit of operation was more than historical. It presented to the minds of men and women not as a contingent state of affairs but as a path of conviction-as a truth. There is much nostalgia for the Main Street venue that the company left behind, and understandably so in a city that has knocked down every one of its old theatres. ${ }^{5}$ But the venue is less important than the ruling idea that conditioned the company's life and continues on, in viral form, today. Like Studio Arena itself, this idea has taken different names, but the one it is best known by is "regional theatre".

\section{Regional Theatre}

Regional theatre is the name given to a group of US "resident" (as opposed to "touring" or "stock") companies that rose to prominence in the late 1950s, and it is represented by the professional association, the League of Resident Theatres (LORT). Currently, there are 74 LORTs, though the number of regional companies who are not counted in one of its four tiers is much greater, probably around 1800 . In Regional Theatre: The Revolutionary Stage (1973), Joseph Zeigler outlines the origins of this important theatre movement and identifies its key features: its non-profit status, its multi-stakeholder orientation, its institutional nature, and its tolerance of (but ambivalence towards) artistic individualism. There is no doubting the seismic impact regional theatre had both at a local level, and in the US as a whole [25].

Although writing at the height of regional theatre's vibrancy, Zeigler warned that it was "a revolution endangered, almost overwhelmed by an obsessive purpose: the creation of a single American National Theatre to rival any in the world" ([25], p. 5). This is a useful insight because it reminds us that regional theatre represents a complicated array of contradictory commitments. Zeigler does not examine these in detail, but they clearly go beyond the identitarian quest for a unitary national drama. One contradiction can be seen haunting Studio Arena seasons. It is the tension between the critical aspects of the theatre's play program and its popular aspects, between the capacity of drama to challenge audiences and its capacity to entertain them. The practical result of this contradiction was ongoing conflict between those who believed that theatre should mirror the beliefs of the community and those who thought that its role was to confront them.

Here the job of the historian is less to contextualise-to re-create Buffalo's lost era of social and cultural affluence- than to show how a principled commitment (and ensuing positions) extended across decades to assert decisive influence. By way of an example, I will briefly describe one incident: the dissolution of the Buffalo Players in 1927. This company had formed four years before, and its short life was dominated by infighting of the bitterest kind. In a series of divisions that exactly parallel those which beset Studio Arena in the 1990s, these massed around opposed interpretations of its mandate. Here is a quotation from an article written when the Players had split into warring "Little Theatre" and "Community Theatre" camps:

5 For an inventory of Buffalo's older theatres, see [22,23]. For an account of the demolition of the Erlanger Theatre, one of the last to go, see ([24], pp. 293-96). 
The moment a group organized to promote the Little Theatre ideal...permits its judgement in the matter of plays to be swayed by popularity or box office receipts, as contrasted with significance in play, it not only ceases to be identifiable as [part of] the Little Theatre movement, but also loses its avowed reason for existence. Paradoxical though it may sound the Little Theatre group does not have to be small and it is often true that the plays become popular. The point is that the plays must be significant whether they are popular or not...The distinguishing mark of Little Theatre enterprises is the complete elimination of box office influence, the insistence upon plays of a character to stimulate knowledge of and love for the drama as an art rather than as casual entertainment...Community Theatre, on the other hand, emphasizes the popularity of the plays selected as evidenced by box office receipts [and] accepts no responsibility for the plays as educators in the art...The Buffalo Players have tried to be both [kinds of company] and the result has been by no means unqualifiedly happy, either for the members or for the development of the drama in Buffalo ([26]).

The result of the struggle between these two ideas of theatre was, an undated note in Studio Arena's archives says, "monumental" [27]. The lease on the Allendale theatre was given up, and the policy of staging light comedies and musicals abandoned. A smaller playhouse was found and an educational wing established that allowed the company to weather the storm of a newly depressed economy. The theatre was re-branded under new leadership and its mission re-articulated as above. If we really want to understand the relation between a theatre and its city, we need to look beyond contingent terms like "Little" and "Community"-beyond "des chapeaux et des manteaux" (hats and coats) in Descartes' phrase- to see that the central truth that polarised the Players shaped the company well beyond it. Du Brock's professionalisation of the theatre saw it emerge out of a phase of artistic self-referentiality and re-engage popular tastes. How far this engagement should go was a matter of hot dispute, however. We might say that for this kind of theatre, the one we now call "regional" (and will, in decades' time, call something else), the tension between the critical and popular dimensions of drama is a defining crux of its existence. Expressed as a division devoid of permanent content but never of emotional value, the tension is the basis for a theatre's phenomenal existence even as it extends through time as an unchanging point of focus and commitment.

Our account would be more than an analysis of facts and details, therefore. It would have the capacity to illuminate the meaning of the city-theatre dyad "from within", to show how it can be conditioned by an ahistorical logic that is both emotionally binding and organisationally effective (Badiou would say "productive of militant fidelities"). It would allow different kinds of insights to be drawn. The first relate to theatre. The critical-popular tension underscoring Studio Arena meant that it was an inherently unstable aesthetic site- a fact probably under-appreciated by its members, forever arguing about the content of annual seasons. But in retrospect, dynamic diversity was key to its operation and value, the "Real" of Studio Arena, what it actually represented. It was not a substitutable function, as government agencies later believed. Sixteen avant-garde companies do not make one regional theatre, just as 16 apples do not make one orange.

The second type of insight relates to the city. Studio Arena was a singular expression of theatrical creativity. It is comparable with other theatres in other cities, to other cultural formations in other periods. But it took root, flourished, and died in Buffalo and understanding it throws a unique light on the workings of the city's cultural imaginary. It allows for some provocative reversals. Perhaps Studio Arena did not collapse because Buffalo's economy declined. Perhaps Buffalo declined because its creative potential was no longer extant. No longer a site for truthful subjectivities, the city could not enjoy the broader definitional benefits that cultural action provides.

Yet the creative possibilities that Studio Arena represent have not died as a figure of thought. As Plato observed, a truth, if it is a truth, is a truth forever. In this sense, I put forward another, and opposite, definition of the word "unmade". It comes from the Athanasian Creed-an early attempt by Christian theologians to describe the nature of God. "Bot on unmade and on mikel is he" is the phrase 
in Old English; or "begotten not made", as Catholics say today. This definition of the word posits "unmade" as meaning: "existing without having yet been made", "uncreated but existent" (Oxford English Dictionary, un'made, adjective): indiscernible, but still present, still there.

"As Buffalo goes, so goes the region", states the city's Comprehensive Plan [28]. "As Studio goes, so goes the rest of the Theatre District", says Irish Classical's Artistic Director Vincent O'Neill [20]. It remains only for the Badiou-ian investigator to close a chain argument: "As goes Buffalo theatre, so goes Buffalo". The conclusion that can be drawn echoes the creative potential we feel when we enter an empty theatre and let its emotional spirit move us: Studio Arena/Buffalo lives.

Conflicts of Interest: The author declares no conflict of interest.

\section{Appendix A. Brief Chronology of Studio Arena Theatre and the City of Buffalo}

1900 Studio Club formed. Buffalo's population 352,387, making it 8th largest city in the USA.

1901 Pan-American Exhibition held.

1910 Buffalo greatest grain port in the world. Economy diverse and flourishing: iron, steel, auto, chemicals, manufactures, agriculture. Population ethnically divided and localised: a WASP elite and Jewish, Irish, Polish, German and Italian neighbourhoods.

1920-1922 Buffalo Players formed. Allendale Theatre rented. Buffalo's population 506,775, making it 11th largest city in the USA. Buffalo banking and utilities start investing in other cities. Wealth and influence exits to New York City, Cleveland and Minneapolis.

1927 Buffalo Players dissolves. Remainder regroup as Studio Theatre under Jane Keeler. Move to Lodge, at corner of Elmwood and Anderson Place. Buffalo makes record profits but population growth slows from $19 \%$ to $13 \%$.

1930 Studio Theatre wins Belasco Cup with Frederick Molnar's The Man who Married a Dumb Wife.

1932 Lodge closed due to fire regulations. Gaiety Theatre offered rent-free by Mike Shea.

1935 Mike Shea dies. Studio Theatre moves to Teck Theatre. Summer seasons at Orchard Park.

1936 Studio Theatre incorporates as an educational institution under the New York State Board of Regents.

1937 Studio Theatre purchases Universalist Church, at corner of Lafayette and Hoyts. Rockefeller grant of $\$ 25,000$ to refurbish. Depression hits Buffalo. Rationalisation and concentration of capital and factory ownership. The city still economically strong, with 13 trunk line railroads and an active port. Companies in the area include Westinghouse, Remington, Bethlehem Steel, Dupont, Union Carbide, Bell Aircraft and Hooker Chemical.

1940-1949 Buffalo experiences successive war booms.

1950 Buffalo's population 580,132, making it 15th largest city in the USA.

1951 Greater Buffalo Development Foundation founded.

1958 Jane Keeler retires. Michael Sinclaire appointed Director of Studio Theatre, then Kay Kingdon.

1959 Opening of St Lawrence Seaway and loss of wheat trade. Political power concentrated in the Democratic Party machine, largely Catholic; economic power in the WASP elite, largely bankers and lawyers.

1962 Neal Du Brock takes over the company as Artistic Director. Comes via Los Angeles and New York, where he was involved in Circle in the Square. Has directed a number of successful, non-professional productions in Buffalo. A Republican mayor, Chester Kowal, elected to office, but the party splits over personality issues. Governor Rockefeller announces plans for a new State University of New York (SUNY) campus at Buffalo.

1964 East Side Community Organisation (later BUILD) founded-an African American association. Decision made to locate new University campus in suburban Amherst. Debate about location of a new football stadium splits media and elite opinion. It is eventually located in Orchard Park. Buffalo chosen for the Model City Program. Attempt at regional consolidation of local police forces defeated at referendum by a handful of county villages. 
1965 Company becomes Studio Arena Theatre, a professional, not-for-profit Equity Theatre. Opens a new theatre in the former Town Casino, at 681 Main Street. Is key player in the regional theatre movement.

1966 Plans to develop Main Street put forward. Chester Kowal replaced as mayor by Democrat Frank Sedita.

1968 Company stages premiere of Edward Albee's Box Mao Box. Buffalo's population 532,759, making it 20th largest city in the USA. African American population increases from $6 \%$ to $10 \%$ over the next 20 years.

1969 Niagara Frontier Transit Authority takes first steps to implement a rapid transit system. Retirement of 'old guard' of Buffalo's civic leaders. White, inner-city residents relocate to the suburbs.

1970 Buffalo population 462,768, 28th largest city in the USA. Regional steel, auto and chemical companies start to withdraw. Over the decade, General Motors, Ford, Bethlehem and Republic Steel shed 50\% of their jobs. OPEC oil crisis of 1973 accelerates de-industrialisation. Union-management relations adversarial. Wages for blue-collar workers increase beyond the national average. Six railroads close. Hopes for an economic focus in light-, medium- and high-technology sectors.

1975 Work on an underground rapid transit system linking downtown with the University begins. Immediately revised to be partially above ground.

1976 Buffalo accedes to court orders to integrate its public schools.

1977 James Griffin, an Independent candidate, becomes mayor and remains in office for 16 years.

1978 Studio Arena receives Federal Economic Development Administration grant and renovates the Palace Burlesque Theatre, a former nightclub, at 710 Main Street, with 637 seats in a thrust stage configuration.

1980 Buffalo's population 350,000, making it 37th largest city in the USA. Manufacturing sector continues to decline. Loss of all but two auto companies. Lower-paid service sector swells. Public funding for the 'sick' city balloons by $110 \%$, constituting nearly $50 \%$ of its annual revenue. A 'Group of Eighteen' leaders put forward a corporate renewal strategy. Downtown development plans accumulate. Horizons Waterfront Commission fiasco. Du Brock fired by Studio Arena Board. David Frank takes over as Artistic Director. Managing directors Brian Wyatt and later Raymond Bonnard appointed. Both leave under a cloud. National Endowment for the Arts funding winds down.

1986 The rapid transit system opens, only half complete. Relations between mayor and city council reach an impasse. Warren Buffett buys Buffalo News and its editorials become less conservative.

1991 Greater Buffalo Development Foundation and Chamber of Commerce merge. Frank resigns at Studio Arena and Gavin Cameron-Webb takes over as Artistic Director.

1992 Studio Two opens as an adjunct experimental space, offering Angels in America and How I Learnt to Drive. Closes almost immediately.

1993 Buffalo Niagara Partnership founded.

1994 Studio Arena stages first of its 'Buffalo Plays': Tom Dudzick's Over the Tavern and A. R. Gurney's The Snow Ball. Buffalo's population 328,648, making it 50th largest city in the USA.

1997 Failure of South Buffalo Redevelopment Plan.

1999 Erie-Niagara Regional Partnership founded. Study finds that over 50\% of membership of local boards are bankers or lawyers.

2003 State Comptroller establishes the Buffalo Fiscal Stability Authority board.

2005 Cultural Resources Advisory Board threatens Studio Arena's funding of \$200,000 annually. Company takes its Johnny Cash musical Ring of Fire to Broadway. It fails. Annual deficit of $\$ 314,473$. Accumulated deficit of $\$ 1.4$ million (approx.) 
2006 Cameron-Webb resigns. Kathleen Gaffney takes over as Artistic Director. In November, Ken Neufeld is fired as Managing Director and Gaffney must do both jobs.

2007 In January, Gaffney lays off 14 Studio Arena staff and scales back seasons to six productions. Moves to include shows by Road Less Travelled and MusicalFare bring out Actors Equity Union against her. In September, merger explored with Artpark but this is rejected at the city level. In December, emergency fundraising nets $\$ 225,000$ and heads off closure. Company downgraded from a LORT ' $\mathrm{B}$ ' theatre to a LORT ' $\mathrm{D}$ '. GFC hits the US economy.

2008 In February, Studio Arena ceases selling tickets and cancels the remainder of its season. In June, files for 'Chapter 11 bankruptcy'. In September, Gaffney is fired.

2009 Studio Arena files for 'Chapter 7 bankruptcy', with debts of $\$ 3$ million (approx.), the majority owed to its own endowment. Buffalo's population 292,648, making it 57th largest city in the USA. City tax revenue falls by $\$ 19$ million. Executive Director of Buffalo's Arts Council, Celeste Lawson, accused of mismanagement, loses re-granting money from New York's State Council on the Arts.

2011 Buffalo's population 261,310, making it 70th largest city in the USA.

\section{References and Notes}

1. Grossman, Allen. “Port Sunlight." Boston Review, 2004. Available online: http://bostonreview.net/grossmanport-sunlight (accessed on 27 August 2016).

2. Timothy Neeson (freelance photographer), in communication with the author, September 2012.

3. Carlson, Marvin. Places of Performance: The Semiotics of Theatre Architecture. New York: Cornell University Press, 1989.

4. Becker, Howard Saul. Art Worlds, rev. ed. Berkeley and Los Angeles: University of California Press, 2008.

5. Hallward, Peter. Badiou: A Subject to Truth. Minneapolis and London: University of Minnesota Press, 2003.

6. Badiou, Alain. Infinite Thought: Truth and the Return to Philosophy. Translated and Edited by Justin Clemens and Oliver Feltham. London and New York: Continuum, 1999, pp. 43-51.

7. Badiou, Alain. Being and Event. Translated by Oliver Feltham. London and New York: Continuum, 2007.

8. Badiou, Alain. The Logics of Worlds: Being and Event. Translated by Alberto Toscano. London and New York: Continuum, 2009, vol. 2.

9. Clemens, Justin. "Doubles of Nothing: The Problem of Binding Truth to Being in the Work of Alain Badiou." Filozofski verstnik 2 (2005): 97-111.

10. Hallward, Peter. “Order and Event: On Badiou's Logics of Worlds." New Left Review 35 (2008): 97-122.

11. Badiou, Alain. St Paul: The Foundation of Universalism. Translated by Ray Brassier. Stanford: Stanford University Press, 2003.

12. Note on Studio Club, Undated, Studio Arena Theatre History, Box 073, Studio Arena Archives, Buffalo State University Library.

13. Chase, Anthony. "Blossom Cohan." Artvoice, 30 March 2006. Available online: http://artvoice.com/issues / v5n13/blossom_cohan.html (accessed on 16 August 2016).

14. Dillaway, Diana. Power Failure: Politics, Patronage, and the Economic Future of Buffalo, New York. Amherst: Prometheus Books, 2006.

15. Goldman, Mark. City on the Edge: Buffalo, New York 1900 to Present. Amherst: Prometheus Books, 2007.

16. Goldman, Mark. High Hopes: The Rise and Decline of Buffalo, New York. Albany: State University of New York Press, 1983.

17. Williams, Lillian Serece. Strangers in the Land of Paradise: The Creation of an African American Community, Buffalo New York, 1900-1940. Bloomington and Indianapolis: University of Indiana Press, 1999.

18. View of Studio Theatre, Roger Gratwick, 1962, Studio Arena Theatre History, Box 073, Studio Arena Archives, Buffalo State University Library.

19. Chase, Anthony. "Saving Studio Arena." Artvoice, 26 December 2007. Available online: http://artvoice.com/ issues/v6n52/saving_studio_arena.html (accessed on 27 August 2016).

20. Studio Arena Theatre History, Box 073, Studio Arena Archives, Buffalo State University Library.

21. Quoted in Richard Huntington. “Singled Out: Arts Community Cries Foul." Buffalo News, 6 November 2005. 
22. Sandhu, Ranjit. Buffalo Theatres Prior to 1930: An Ever-growing Index of References Compiled from Scrapbooks and Card Catalogues at the Buffalo and Erie County Public Library and the Buffalo and Erie County Historical Society, From Previous Researchers and From Original Research. Privately printed, 2002.

23. Sandu, Ranjit. "Buffalo's Forgotten Theatres." 2002. Available online: http://www.buffaloah.com/h/movie/ sandhu/index.html (accessed on 21 June 2012).

24. Kunz, George. Buffalo Memories: Gone but Not Forgotten. Buffalo: Canisius College Press, 2002.

25. Zeigler, Joseph Wesley. Regional Theatre: The Revolutionary Stage. Minneapolis: University of Minnesota Press, 1973.

26. Buffalo Artists Register, Lee Heacock, 1927, Studio Arena Theatre History, Box 073, Studio Arena Archives, Buffalo State University Library.

27. Note on transition from Buffalo Players to Studio Theatre, Studio Arena Theatre History, Box 073, Studio Arena Archives, Buffalo State University Library.

28. “Buffalo Comprehensive Plan.” 2011. Available online: http://www.ci.buffalo.ny.us/files/1_2_1/Mayor/ COB_Comprehensive_Plan/index.html (accessed on 12 May 2011).

(C) 2016 by the author; licensee MDPI, Basel, Switzerland. This article is an open access article distributed under the terms and conditions of the Creative Commons Attribution (CC-BY) license (http://creativecommons.org/licenses/by/4.0/). 